\title{
Pengaruh Profitabilitas Terhadap Pengeluaran Zakat dengan Ukuran Perusahaan Sebagai Variabel Moderasi Pada Bank Umum Syariah di Indonesia
}

\begin{abstract}
Ani Sumiyati
Abstract

This study aims to describe the description of profitability, zakat expenditure and company size, and verify the effect of profitability on zakat expenditure on firm size as a moderating variable in Islamic commercial banks in Indonesia. Profitability is measured using Return on Assets (ROA) and company size is measured using total assets. This study uses a quantitative approach with Moderated Regression Analysis (MRA) to analyze data. The number of samples used in this study were 48 observational data from eight Islamic public banks in Indonesia during the 2011-2016 period. The findings of this study are that profitability does not affect the expenditure of zakat and the size of the company is not able to moderate the effect of profitability on zakat expenditure. This study also found that the size of the company in this study only served as a predictor variable in the relationship model formed.
\end{abstract}

Keywords. islamic bank; MRA; profitability; company size; zakat

\begin{abstract}
Abstrak
Penelitian ini bertujuan untuk mendeskripsikan gambaran profitabilitas, pengeluaran zakat dan ukuran perusahaan, serta memverifikasi pengaruh profitabilitas terhadap pengeluaran zakat dengan ukuran perusahaan sebagai variabel moderasi pada bank umum syariah di Indonesia. Profitabilitas diukur dengan menggunakan Return On Assets (ROA) dan ukuran perusahaan diukur dengan menggunakan total aset. Penelitian ini menggunakan pendekatan kuantitatif dengan Moderated Regression Analysis (MRA) untuk menganalisis data. Jumlah sampel yang digunakan dalam penelitian ini adalah 48 data observasi dari delapan bank umum syariah di Indonesia selama periode 2011-2016. Temuan penelitian ini adalah profitabilitas tidak berpengaruh terhadap pengeluaran zakat dan ukuran perusahaan tidak mampu memoderasi pengaruh profitabilitas terhadap pengeluaran zakat. Penelitian ini juga menemukan bahwa ukuran perusahaan dalam penelitian ini hanya berperan sebagai variabel prediktor dalam model hubungan yang dibentuk.
\end{abstract}

Kata kunci: bank umum syariah; MRA; profitabilitas; ukuran perusahaan; zakat perusahaan

Corresponding author. Email. anisumiyati23@gmail.com

How to cite this article. Sumiyati, A. (2017). Pengaruh Profitabilitas Terhadap Pengeluaran Zakat dengan Ukuran Perusahaan Sebagai Variabel Moderasi Pada Bank Umum Syariah di Indonesia. Jurnal Pendidikan Akuntansi Dan Keuangan, 5(1), 1-10. Retrieved from http://ejournal.upi.edu/index.php/JPAK/article/view/15379

History of article. Received: Agustus 2016, Revision: November 2016, Published: Januari 2017

\section{Pendahuluan}

Perbankan merupakan salah satu sarana strategis dalam pembangunan ekonomi. Praktik perbankan syariah lahir dengan dilatarbelakangi oleh kebutuhan masyarakat muslim Indonesia dan kesadaran masyarakat akan bunga bank sebagai riba. Jumlah bank umum syariah di Indonesia terus mengalami peningkatan dari tahun ke tahun. Peningkatan bank umum syariah mencerminkan bahwa potensi perbankan syariah di Indonesia sangat positif dan tentunya akan meningkatkan jumlah wajib zakat perusahaan.
Sebagaimana diatur dalam UU No. 38 tahun 1999 Pasal 11 Ayat 2 Poin b bahwa, "perdagangan dan perusahaan merupakan harta yang dikenai zakat." Di samping itu, dalam UU No. 23 tahun 2011 yang merupakan UndangUndang Pengelolaan Zakat terbaru, dijelaskan dalam Pasal 4 Ayat 2 Poin g bahwa, "perindustrian termasuk ke dalam bagian dari zakat mal." Zakat mal sebagaimana dimaksud pada ayat tersebut merupakan harta yang dimiliki oleh muzaki perseorangan atau badan usaha. 
Bank umum syariah sebagai lembaga yang bergerak dalam jasa keuangan syariah, diwajibkan untuk menjadi pengelola zakat. Hal ini merupakan peran dan fungsi yang melekat pada bank syariah untuk mengelola dana-dana sosial, termasuk di dalamnya zakat, infak dan sedekah.

Berdasarkan riset tahun 2011 yang berjudul Economic Estimation and Determinations of Zakat Potential in Indonesia, potensi zakat di Indonesia mencapai angka Rp217 triliun atau setara dengan 3,40\% dari total PDB untuk setiap tahunnya. Potensi zakat nasional tersebut diklasifikasikan ke dalam tiga kelompok besar, yakni potensi zakat rumah tangga, potensi zakat industri (perusahaan) swasta dan BUMN, serta potensi zakat tabungan.

Adapun potensi dan realisasi zakat perusahaan bank umum syariah pada tahun 2015 adalah sebagai berikut.

Tabel 1. Potensi dan Realisasi Zakat Perusahaan BUS (dalam ribuan rupiah)

\begin{tabular}{rlrr} 
No & Nama BUS & $\begin{array}{r}\text { Tarif Zakat } \\
(\mathbf{2 , 5 \%} \text { x laba) }\end{array}$ & $\begin{array}{r}\text { Realisasi zakat tahun } \\
\mathbf{2 0 1 5}\end{array}$ \\
\hline 1 & BMI & 2.722 .746 & 1.429 .334 \\
2 & BNIS & 7.694 .200 & 7.701 .000 \\
3 & BSM & 9.592 .982 & 9.592 .982 \\
4 & BRIS & 4.226 .725 & 4.001 .000 \\
5 & BMS & 428.907 & 428.907 \\
6 & BCAS & 797.303 & 0 \\
7 & BJBS & 398.746 & 0 \\
8 & BPS & 1.932 .632 & 1.932 .632 \\
9 & BSB & 1.016 .642 & 0 \\
10 & BVS & 0 & 0 \\
11 & BMbS & 0 & 0 \\
12 & BTPNS & 6.261 .100 & $\mathbf{2 5 . 0 8 5 . 8 5 5}$ \\
\hline
\end{tabular}

Sumber: Annual Report Bank Umum Syariah di Indonesia Tahun 2015

Berdasarkan Tabel 1 dapat diketahui bahwa potensi zakat bank umum syariah mencapai Rp48.954.275 ribu, sementara realisasinya hanya mencapai Rp25.085.855 ribu atau setara dengan 51,24\%. Dengan demikian, masih ada $\mathrm{Rp} 23.868 .420$ ribu atau $48,76 \%$ dana zakat perusahaan dari BUS di Indonesia yang belum terungkap. Hal tersebut membuktikan bahwa penghimpunan zakat perusahaan dari BUS di Indonesia masih sangat rendah.

Dampak yang ditimbulkan bagi bank umum syariah yang tidak mengeluarkan zakat perusahaan adalah tidak terpenuhinya prinsip syariah yang menjadi dasar dalam kegiatan operasional perusahaan. Selain itu, dampak sosial yang mungkin ditimbulkan karena ketidakadilan ini adalah adanya jurang pemisah antara si kaya dan si miskin. Sementara dampak ekonomi yang timbul adalah inflasi karena sikap konsumtif dari pihak-pihak yang harta kekayaannya terpusat pada mereka.

Zakat perusahaan merupakan amanah dan tanggung jawab bagi perusahaan sesuai dengan aturan agama dan aturan perundangundangan sehingga tujuan kemaslahatan dan keberkahan dapat tercapai. Perusahaan yang berorientasi pada zakat bukan berarti melupakan mencari laba dari sisi ekonomi, tetapi pencapaian laba yang maksimal adalah sasaran antara dan pencapaian zakat adalah tujuan akhirnya. Sebagaimana pernyataan Ikhwan (2000) bahwa, Pencapaian kinerja perusahaan berdasar zakat tetap harus melalui pencapaian kinerja perusahaan yang lain dari sisi likuiditas, solvabilitas, profitabilitas sebagai sasaran antara.

Selain itu, zakat adalah salah satu komitmen perusahaan kepada masyarakat sehingga besarnya komitmen tergantung pada besarnya kapasitas perusahaan. Menurut Sari (2012), "perusahaan yang skalanya besar cenderung lebih banyak mengungkapkan tanggung jawab sosial daripada perusahaan yang mempunyai skala kecil." Dalam hal ini, tanggung jawab sosial yang dimaksud adalah zakat perusahaan.

\section{Landasan Teori}

\section{Syari'ah Enterprise Theory}

Dalam konteks syariah, organisasi secara ideal dibangun dan dikembangkan dengan menggunakan metafora amanah, dimana realitas organisasi bagi perusahaan yang berbasis nilai syariah adalah menggunakan konsep yang berorientasi pada zakat (zakat oriented), bukan lagi berorientasi pada laba (profit oriented). Konsep yang diusung dalam Shari'ah Enterprise Theory lebih luas, yaitu perusahaan bertanggung jawab 
pada Tuhan, stakeholders, dan alam. Konsekuensi lain dari Shari'ah Enterprise Theory yakni tidak menggunakan konsep laba, tapi sebaliknya menggunakan konsep nilai tambah (value added), atau lebih tepatnya menggunakan Shari'ah Value Added yang nantinya disajikan dalam Shari'ah Value Added Statement (Triyuwono, 2012: 362).

\section{Bank Syariah}

Menurut Undang-Undang No. 21 tahun 2008 Pasal 1 Ayat 7, "Bank Syariah adalah bank yang menjalankan kegiatan usahanya berdasarkan prinsip syariah dan menurut jenisnya terdiri atas Bank Umum Syariah dan Bank Pembiayaan Rakyat Syariah." Dalam tujuannya bank syariah dilarang untuk menghasilkan laba maksimum, tetapi bank syariah tetap didorong untuk menghasilkan laba tanpa harus melanggar prinsip syariah dan tanpa harus meninggalkan kontribusinya dalam peningkatan kualitas perekonomian umat (masyarakat umum).

\section{Profitabilitas}

Profitabilitas menggambarkan kemampuan perusahaan untuk mendapatkan laba melalui semua kemampuan, dan sumber yang ada seperti kegiatan penjualan, kas, modal jumlah karyawan, jumlah cabang, dan sebagainya. (Harahap, 2008: 304)

Profitabilitas diukur dengan menggunakan Return on Assets (ROA). ROA merupakan metode pengukuran yang paling obyektif yang didasarkan pada data akuntansi yang tersedia dan besarnya ROA dapat mencerminkan hasil dari serangkaian kebijakan perusahaan terutama perbankan (Stiawan, 2009).

\section{Zakat Perusahaan}

Menurut Nurhayati dan Wasilah (2013: 301), "zakat perusahaan adalah zakat yang didasarkan atas prinsip keadilan serta hasil ijtihad para ahli fikih." Para ulama kontemporer menganalogikan zakat perusahaan pada zakat perdagangan, karena jika dipandang dari aspek legal dan ekonomi, kegiatan inti sebuah perusahaan adalah berpijak pada kegiatan trading atau perdagangan. Setiap harta dan hasil usaha harus dikeluarkan zakatnya karena zakat merupakan instrumen untuk mewujudkan keadilan antarsesama pelaku usaha.

\section{Ukuran Perusahaan}

Ukuran perusahaan merupakan nilai yang menunjukkan besar kecilnya perusahaan yang dapat dijadikan sebagai faktor yang menentukan kemampuan perusahaan dalam menghasilkan laba. Ukuran perusahaan lebih cenderung dilihat dari total aset mengingat produk utama perbankan adalah pembiayaan serta investasi dan juga total aset suatu perusahaan lebih stabil dari tahun ke tahun. Davydenko (2010: 12) mengungkapkan bahwa, "Size is described by the accounting value of banks total assets. Size is an important determinant of profitability."

Dalam mengukur ukuran perusahaan, sebagian besar penelitian sering menggunakan proksi logaritma natural dari aktiva atau aset. Seperti diungkapkan Asnawi (2006) bahwa Proksi size biasanya adalah total aset perusahaan. Karena aset biasanya dapat sangat besar nilainya, dan untuk menghindari bias skala maka besaran aset perlu dikompres. Secara umum proksi size dipakai logaritma atau logaritma natural (Ln) aset.

Logaritma natural dari total aset ini digunakan untuk mengurangi perbedaan signifikan antara ukuran perusahaan yang terlalu besar dengan ukuran perusahaan yang terlalu kecil. Konversi bentuk logaritma natural bertujuan untuk membuat data total aset terdistribusi dengan normal.

\section{Hipotesis}

Berdasarkan paparan dalam kerangka pemikiran, hipotesis dalam penelitian ini dirumuskan sebagai berikut.

1. Profitabilitas berpengaruh positif terhadap pengeluaran zakat.

2. Ukuran perusahaan memoderasi pengaruh profitabilitas terhadap pengeluaran zakat.

\section{Metode Penelitian}

Desain penelitian yang digunakan dalam penelitian ini adalah penelitian kuantitatif, menggunakan metode penelitian deskriptif dan verifikatif. Metode penelitian deskriptif digunakan untuk mengetahui gambaran variabel profitabilitas, pengeluaran zakat, dan ukuran perusahaan. Sementara 
metode penelitian verifikatif digunakan untuk mengetahui pengaruh profitabilitas terhadap pengeluaran zakat dengan ukuran perusahaan sebagai variabel moderasi pada bank umum syariah di Indonesia.

Variabel bebas dalam penelitian ini adalah profitabilitas, sementara variabel terikat yang digunakan adalah pengeluaran zakat, yakni berupa zakat perusahaan. Adapun varibel moderator yang digunakan adalah ukuran perusahaan. Populasi dalam penelitian ini adalah Bank Umum Syariah yang beroperasi di Indonesia pada tahun 2011-2016. Teknik pengambilan sampel yang digunakan adalah Purposive Sampling dengan kriteria (a) Merupakan Bank Umum Syariah yang ada di Indonesia (b) Telah mempublikasikan laporan keuangan yang telah diaudit selama kurun waktu 2011-2016 atau disesuaikan dengan ketersediaan pada website masing-masing bank pada masa periode tersebut.

\section{Hasil Dan Pembahasan}

Uji Asumsi Klasik

Berdasarkan pengujian data, dapat dikatakan bahwa model regresi telah memenuhi uji normalitas, dan heteroskedastisitas, namun belum memenuhi syarat autokorelasi karena tidak menghasilkan kesimpulan yang pasti apakah terjadi gejala autokorelasi atau tidak. Adapun cara yang dilakukan untuk mengatasi masalah tersebut adalah dengan menggunakan uji Run Test sehingga dapat disimpulkan bahwa tidak terdapat gejala autokorelasi.

\section{Analisis Regresi Moderasi}

Moderated Regression Analysis (MRA) merupakan analisis khusus regresi berganda linier dimana persamaan regresinya mengandung unsur interaksi (perkalian dua atau lebih variabel independen). Pada penelitian ini, interaksi yang terjadi adalah perkalian antara profitabilitas dan ukuran perusahaan terhadap profitabilitas dan pengeluaran zakat. Pengolahan analisis regresi moderasi dilakukan dengan membandingkan tiga persamaan regresi untuk menentukan jenis variabel moderator sebagai berikut.

Ln Zakat $=\alpha+\beta_{1}$ ROA $+\varepsilon$

Ln Zakat $=\alpha+\beta_{1}$ ROA $+\beta_{2} \operatorname{LnTA}+\varepsilon$

\section{Ln Zakat $=\alpha+\beta_{1}$ ROA $+\beta_{2}$ LnTA + $\beta_{3} \operatorname{ROA}^{*} \operatorname{LnTA}+\varepsilon$}

Untuk menentukan bahwa ukuran perusahaan merupakan variabel moderasi atau tidak, dapat dilihat dari tingkat signifikansi $\beta_{2}$ dan $\beta_{3}$. Jika dalam persamaan ketiga $\beta_{2}=0$ (tidak signifikan) dan $\beta_{3} \neq 0$ (signifikan), maka ukuran perusahaan termasuk dalam pure moderator. Akan tetapi, jika ukuran perusahaan bukan termasuk pure moderator maka dapat dilihat perbandingannya dengan persamaan pertama dan kedua, apakah ukuran perusahaan termasuk dalam quasi moderator, homologizer moderator, atau prediktor moderator.

Setelah melakukan pengolahan data diperoleh persamaan regresi moderasi sebagai berikut.

$$
\begin{aligned}
& \text { Zakat }=12,237+3,099 \mathrm{ROA}+\mathcal{E} \\
& \text { Zakat }=-194,078+3,952 \text { ROA }+6,835 \text { Ln_TA } \\
& +\varepsilon \\
& \text { Zakat }=-212,562+24,788 \mathrm{ROA}+7,449 \\
& \text { Ln_TA - 0,693 Moderasi + E }
\end{aligned}
$$

Variabel ukuran perusahaan yang secara teori dianggap mampu memoderasi pengaruh profitabilitas terhadap pengeluaran zakat, ternyata hal tersebut tidak terbukti. Berdasarkan hasil analisis melalui SPSS diketahui bahwa ukuran perusahaan dalam penelitian ini bukan merupakan pure moderasi karena $\beta_{2}$ dalam persamaan ketiga terbukti signifikan, sementara $\beta_{3}$ terbukti tidak signifikan.

Setelah dilakukan perbandingan dengan persamaan kedua, maka diketahui bahwa ukuran perusahaan merupakan sebuah variabel independen karena $\beta_{2}$ dalam persamaan kedua dan ketiga terbukti signifikan, sehingga variabel moderasi dalam penelitian ini hanya berperan sebagai variabel prediktor (independen) dalam model hubungan yang dibentuk.

Uji Keberartian Regresi (Uji F)

Uji keberartian regresi digunakan agar dapat menguji kemampuan variabel bebas untuk menjelaskan perilaku dari variabel terikat. Berdasarkan hasil pengolahan data, diketahui bahwa nilai $\mathrm{F}$ hitung persamaan pertama adalah sebesar 1,799 dengan probabilitas 0,186 . $F$ tabel pada tingkat signifikansi 0,05 dengan $\mathrm{dk}$ pembilang 1 , dan

4 | Jurnal Pendidikan Akuntansi dan Keuangan

DOI.10.17509/jpak.v5i1.15379| http://ejournal.upi.edu/index.php/JPAK 
$\mathrm{dk}$ penyebut 46 , maka diperoleh nilai $\mathrm{F}$ tabel adalah sebesar 4,05 sehingga terlihat bahwa nilai $\mathrm{F}$ hitung $\leq \mathrm{F}$ tabel yakni $1,799 \leq 4,05$ maka Ho diterima yang artinya regresi tidak berarti. Hal tersebut menunjukkan bahwa profitabilitas tidak berpengaruh terhadap pengeluaran zakat. Adapun nilai $\mathrm{F}$ hitung dari persamaan ketiga adalah sebesar 28,159 dengan probabilitas 0,000 . F tabel pada tingkat signifikansi 0,05 dengan $\mathrm{dk}$ pembilang 3 , dan $\mathrm{dk}$ penyebut 44 , maka diperoleh nilai $\mathrm{F}$ tabel adalah sebesar 2,82 sehingga terlihat bahwa nilai $\mathrm{F}$ hitung $\leq \mathrm{F}$ tabel yakni $28,159 \leq 28,2$ maka Ho diterima yang artinya regresi tidak berarti. Hal tersebut menunjukkan bahwa ukuran perusahaan tidak mampu memoderasi pengaruh profitabilitas terhadap pengeluaran zakat.

\section{Uji Keberartian Koefisien Regresi (Uji t)}

Uji keberartian koefisien regresi pada dasarnya menunjukkan seberapa jauh pengaruh satu variabel independen dalam menerangkan variasi variabel dependen secara individual dengan menganggap variabel independen lainnya bernilai tetap. Adapun rumusan hipotesis dalam penelitian ini adalah sebagai berikut.

\section{Persamaan pertama}

Ho: $\beta_{1} \leq 0$, Profitabilitas tidak berpengaruh positif terhadap pengeluaran zakat

Ha: $\beta_{1}>0$, Profitabilitas berpengaruh positif terhadap pengeluaran zakat

Berdasarkan hasil pengolahan data, dapat diketahui bahwa nilai $t_{\text {tabel }}$ dengan tingkat signifikansi $5 \%$ dan $\mathrm{dk}=\mathrm{n}-\mathrm{k}-1=48-1-1$ $=46$ adalah 1,67866. Sementara dari hasil pengujian diperoleh kesimpulan bahwa variabel profitabilitas memiliki nilai $t_{\text {hitung }}<$ nilai $t_{\text {tabel }}$, yaitu sebesar 1,341 < 1,67866 dengan nilai signifikansi 0,186 , artinya profitabilitas tidak berpengaruh terhadap pengeluaran zakat. Hasil pengujian ini menunjukkan bahwa hipotesis pertama dalam penelitian ini ditolak.

\section{Persamaan ketiga}

Ho: $\beta 3=0$, Ukuran perusahaan tidak memoderasi pengaruh profitabilitas terhadap pengeluaran zakat

Ha: $\beta 3 \neq 0$, Ukuran perusahaan memoderasi pengaruh profitabilitas terhadap pengeluaran zakat
Berdasarkan hasil pengolahan data, dapat diketahui bahwa nilai tabel dengan tingkat signifikansi $5 \%$ dan $\mathrm{dk}=\mathrm{n}-\mathrm{k}-1=48-3-1$ $=44$ adalah 1,68023. Sementara dari hasil pengujian diperoleh kesimpulan bahwa variabel profitabilitas memiliki nilai $t_{\text {hitung }}<$ nilai $t_{\text {tabel }}$, yaitu sebesar 0,602 < 1,68023 dengan nilai signifikansi 0,550 , artinya profitabilitas tidak berpengaruh terhadap pengeluaran zakat. Variabel ukuran perusahaan memiliki nilai $t_{\text {hitung }}>$ nilai $t_{\text {tabel }}$, yaitu sebesar 5,193>1,68023 dengan nilai signifikansi 0,000 , artinya terdapat pengaruh positif antara ukuran perusahaan terhadap pengeluaran zakat. Sementara variabel moderasi, yaitu interaksi antara profitabilitas dengan ukuran perusahaan memiliki nilai $t_{\text {hitung }}$ $<$ nilai $t_{\text {tabel}}$, yaitu sebesar $-0,506<1,68023$ dengan nilai signifikansi 0,615 , artinya ukuran perusahaan tidak mampu memoderasi pengaruh profitabilitas terhadap pengeluaran zakat. Hasil pengujian ini menunjukkan bahwa hipotesis kedua dalam penelitian ini ditolak.

\section{Pengaruh Profitabilitas terhadap Pengeluaran Zakat Perusahaan \\ Profitabilitas berhubungan dengan} kondisi kinerja keuangan bank dan tingkat kesehatan bank. Semakin tinggi profitabilitas yang dimiliki bank, maka semakin baik pula kemampuan ekonomi perusahaan dan tingkat kesehatannya. Hal tersebut tentunya memengaruhi kemampuan bank untuk mengeluarkan zakat perusahaan, karena peningkatan kemampuan ekonomi tersebut harus dibarengi dengan kepedulian dan pemenuhan tanggung jawab sosial perusahaan untuk membayar zakat.

Berdasarkan hasil uji keberartian regresi (Uji F) diketahui bahwa $\mathrm{F}$ hitung < F tabel, maka Ho diterima dan Ha ditolak yang berarti bahwa ukuran perusahaan tidak mampu memoderasi pengaruh profitabilitas terhadap pengeluaran zakat. Hasil pengujian keberartian koefisien regresi (Uji t) pada variabel profitabilitas yang diukur dengan Return On Assets (ROA) menunjukkan bahwa profitabilitas tidak berpengaruh terhadap pengeluaran zakat. Hal tersebut terlihat dari nilai koefisien variabel profitabilitas yang memiliki nilai kurang dari tabel.

Hasil pengujian ini tidak sejalan dengan pendapat Ikhwan (2000) yang 
menyatakan bahwa laba dan kinerja keuangan berpengaruh terhadap zakat perusahaan, artinya bahwa semakin besar laba dan nilai kinerja perusahaan akan mengakibatkan semakin besar pula dana zakat perusahaan. Implikasi manajemen yang diharapkan dari pernyataan tersebut adalah perusahaan memiliki kesadaran sendiri bahwa perusahaan yang berorientasi pada zakat sebenarnya berorientasi pada laba dan kinerja perusahaan secara keseluruhan.

Maka dari itu, penolakan hipotesis dalam penelitian ini disebabkan karena terdapat beberapa bank umum syariah yang belum memiliki kebijakan terkait pengeluaran zakat perusahaan dan para pengelola bank belum memiliki kesadaran penuh untuk membayar zakat perusahaan. Jika dilihat dari laba yang diperoleh perusahaan, nilai tersebut terlihat memenuhi nishab untuk membayar zakat perusahaan. Akan tetapi bank masih enggan menunaikan kewajibannya untuk membayar zakat. Hal ini membuktikan bahwa manajemen bank belum mengutamakan orientasi zakat dalam operasional perusahaannya.

Namun demikian, hipotesis pertama dalam penelitian ini merupakan pengaruh profitabilitas terhadap pengeluaran zakat sehingga laba yang diperoleh harus dibandingkan dengan total aset yang dimiliki oleh bank. Laba yang diperoleh memang terbilang cukup tinggi, hanya saja jika dibandingkan dengan total aset yang nilainya sudah mencapai puluhan triliun, maka hasil perbandingannya akan rendah. Dengan demikian, penolakan hipotesis pertama dalam penelitian ini adalah karena nilai laba yang diperoleh bank masih jauh dari nilai total aset, sehingga ketika dibandingkan hasilnya masih belum memenuhi standar.

Hasil pengujian tersebut tidak sejalan dengan hasil penelitian yang dilakukan oleh Ikhwan (2000), Zaitun (2001) yang menunjukkan hasil bahwa laba mempunyai pengaruh positif signifikan terhadap zakat perusahaan. Hasil penelitian ini juga berbeda dengan hasil penelitian Jayanti et al (2015) yang melakukan penelitian pada enam BUS serta Syaifudin (2016) yang melakukan penelitian pada tiga BUS dan dua UUS yang menemukan hasil bahwa ROA berpengaruh terhadap zakat. Akan tetapi hasil penelitian ini sejalan dengan hasil penelitian Rokhmana (2015) yang menemukan hasil bahwa ROA tidak berpengaruh terhadap zakat pada Bank Umum Syariah periode 20102014.

\section{Pengaruh Profitabilitas terhadap Pengeluaran Zakat dengan Ukuran Perusahaan sebagai Variabel Moderasi}

Untuk dapat meningkatkan nilai zakat perusahaan, yaitu agar kenaikan hartanya dapat melampaui nishab yang ditentukan, maka diperlukan skala operasi yang cukup besar. Semakin besar total aset yang dimiliki bank, maka laba yang diperoleh bank juga akan meningkat, sehingga sangat memungkinkan bagi bank untuk menunaikan kewajibannya dalam membayar zakat perusahaan.

Dalam penelitian ini, terlihat bahwa ukuran perusahaan yang diukur dengan total aset bank cenderung mengalami peningkatan untuk setiap tahunnya. Hanya saja peningkatan tersebut tidak dibarengi dengan peningkatan profitabilitas bank, karena profitabilitas yang dimiliki bank umum syariah masih belum stabil dan cenderung menurun. Hal tersebut berarti bahwa peningkatan total aset belum seimbang dengan pembelanjaan sehingga berimbas pada nilai profitabilitas bank yang menurun. Akan tetapi, dengan nilai profitabilitas yang cenderung menurun dan nilai ukuran perusahaan yang cenderung meningkat, bank umum syariah mampu meningkatkan pembayaran zakat perusahaan, sehingga peningkatan zakat perusahaan tersebut diduga karena pengaruh dari ukuran perusahaan yang meningkat pula.

Berdasarkan hasil uji keberartian regresi (Uji F) diketahui bahwa $\mathrm{F}$ hitung < F tabel, maka Ho diterima dan Ha ditolak yang berarti bahwa ukuran perusahaan tidak mampu memoderasi pengaruh profitabilitas terhadap pengeluaran zakat. Hasil pengujian keberartian koefisien regresi (Uji t) pada variabel profitabilitas yang diukur dengan Return On Assets (ROA) menunjukkan bahwa profitabilitas tidak berpengaruh terhadap pengeluaran zakat. Hal tersebut terlihat dari nilai koefisien variabel profitabilitas yang memiliki nilai kurang dari tabel.

Sementara variabel ukuran perusahaan yang diukur dengan logaritma natural total aset menunjukkan terdapat pengaruh positif terhadap pengeluaran zakat. Hal tersebut 
ditunjukkan dengan nilai koefisien variabel ukuran perusahaan yang lebih besar dari $t_{\text {tabel. }}$. Hasil ini sejalan dengan pendapat Sari (2012) yang menyatakan bahwa "perusahaan yang skalanya besar cenderung lebih banyak mengungkapkan tanggung jawab sosial daripada perusahaan yang mempunyai skala kecil.” Tanggung jawab sosial yang dimaksud termasuk di dalamnya adalah zakat perusahaan.

Adapun untuk variabel moderasi yang merupakan interaksi antara profitabilitas dan ukuran perusahaan menunjukkan hasil bahwa variabel moderasi tidak berpengaruh terhadap pengeluaran zakat. Hal ini ditunjukkan dengan nilai koefisien variabel moderasi yang memiliki nilai kurang dari $t_{\text {tabel}}$. Hasil penelitian ini tidak mendukung hipotesis awal yang menyatakan bahwa ukuran perusahaan mampu memoderasi pengaruh profitabilitas terhadap pengeluaran zakat. Hasil penelitian ini juga tidak sejalan dengan Shari'ah Enterprise Theory yang dikemukakan oleh Triyuwono (2012), dimana realitas organisasi bagi perusahaan yang berbasis nilai syariah adalah menggunakan konsep yang berorientasi pada zakat, bukan lagi berorientasi pada laba.

Penolakan hipotesis kedua dalam penelitian ini disebabkan karena ukuran perusahaan ternyata bukan merupakan variabel pure moderator, melainkan sebagai variabel prediktor (independen). Variabel ukuran perusahaan dianggap mampu berpengaruh secara langsung terhadap pengeluaran zakat. Hal tersebut dibuktikan dengan peningkatan ukuran perusahaan yang dibarengi dengan peningkatan zakat perusahaan.

Penyebab lainnya adalah belum tegasnya aturan atau regulasi terkait pengeluaran zakat khususnya zakat perusahaan, baik dari segi hukum maupun teknis perhitungannya. Seperti halnya PT. Bank BCA Syariah dan PT. Bank Syariah Bukopin yang selama periode penelitian yaitu tahun 2011 sampai tahun 2016 tidak memenuhi kewajibannya untuk membayar zakat perusahaan. Dalam perkembangannya, PT. Bank Panin Syariah juga tidak membayar zakat perusahaan sampai tahun 2013. Akan tetapi, sejak tahun 2014 PT. Bank Panin Syariah mulai menunaikan kewajibannya untuk membayar zakat perusahaan, meskipun pembayaran zakat PT. Bank Panin Syariah mengalami penurunan untuk tahun 2015 dan 2016. Adapun bank umum syariah lainnya masih tetap konsisten untuk memenuhi kewajibannya dalam membayar zakat perusahaan, meskipun terdapat beberapa bank yang mengalami penurunan pembayaran zakat perusahaan.

Berdasarkan pemaparan tersebut, dapat ditarik kesimpulan bahwa hasil penelitian ini menolak hipotesis awal penelitian yang menyatakan bahwa ukuran perusahaan mampu memoderasi pengaruh profitabilitas terhadap pengeluaran zakat. Di satu sisi, peningkatan profitabilitas mungkin akan meningkatkan kemampuan bank dalam mempertahankan keberlangsungan usahanya, namun di sisi lain peningkatan profitabilitas belum tentu akan meningkatkan kesadaran pihak manajemen bank untuk memenuhi kewajiban sosialnya dalam membayar zakat perusahaan. Kegiatan operasional bank umum syariah di Indonesia masih dalam tahap peningkatan pangsa pasar, sehingga segala bentuk pengeluaran termasuk pengeluaran zakat masih banyak pertimbangan. Hal tersebut yang diduga menyebabkan ukuran perusahaan tidak mampu memoderasi pengaruh profitabilitas terhadap pengeluaran zakat.

Penolakan hipotesis dalam penelitian ini bertentangan dengan hasil penelitian Firmansyah dan Rusydiana (2013) yang menyatakan bahwa variabel ukuran perusahaan dapat memoderasi pengaruh profitabilitas terhadap pengeluaran zakat perusahaan pada Bank Umum Syariah di Indonesia. Akan tetapi, penolakan hipotesis dalam penelitian ini sesuai dengan hasil penelitian Syaifudin (2016) yang menunjukkan hasil bahwa size bank yang diproksi dengan total aset tidak mampu memoderasi hubungan kinerja keuangan dengan zakat bank syariah. Hal ini menunjukkan bahwa bank umum syariah belum memprioritaskan tujuan sosial dalam keberlangsungan usahanya.

\section{Kesimpulan}

Berdasarkan hasil penelitian dan pembahasan yang telah dilakukan tentang pengaruh profitabilitas terhadap pengeluaran zakat dengan ukuran perusahaan sebagai variabel moderasi, maka dapat disimpulkan bahwa (1) Gambaran profitabilitas yang diukur dengan Return On Assets (ROA) pada bank 
umum syariah di Indonesia selama tahun 20112016 terlihat masih belum stabil dan cenderung menurun dengan rata-rata sebesar $-0,13 \%$. Pengeluaran zakat perusahaan pada bank umum syariah di Indonesia selama tahun 20112016 masih belum stabil tetapi cenderung mengalami peningkatan dengan rata-rata sebesar $-2,70 \%$. Sementara ukuran perusahaan yang diukur dengan total aset pada bank umum syariah di Indonesia selama tahun 2011-2016 cenderung mengalami peningkatan untuk setiap tahunnya dengan rata-rata sebesar $12,32 \%$. (2) Profitabilitas tidak berpengaruh terhadap pengeluaran zakat. (3) Ukuran perusahaan tidak mampu memoderasi pengaruh profitabilitas terhadap pengeluaran zakat.

\section{Daftar Pustaka}

Asnawi, S. K. (2006). Metodologi Penelitian Keuangan: Prosedur, Ide, dan Kontrol. Yogyakarta: Graha Ilmu.

Bank Muamalat Indonesia. (2016). Laporan Keuangan dan Tahunan. [Online]. Diakses dari www.muamalatbank.co.id

Bank Victoria Syariah. (2016). Laporan Keuangan dan Tahunan. [Online]. Diakses dari www.bankvictoriasyariah.co.id

BCA Syariah. (2016). Laporan Keuangan dan Tahunan. [Online]. Diakses dari www.bcasyariah.co.id

BJB Syariah. (2016). Laporan Keuangan dan Tahunan. [Online]. Diakses dari www.bjbsyariah.co.id

BNI Syariah. (2016). Laporan Keuangan dan Tahunan. [Online]. Diakses dari www.bnisyariah.co.id

BRI Syariah. (2016). Laporan Keuangan dan Tahunan. [Online]. Diakses dari www.brisyariah.co.id

BTPN. (2016). Laporan Keuangan dan Tahunan. [Online]. Diakses dari www.btpn.com

Davydenko, A. (2010). Determinants of Bank Profitability in Ukraine. Undergraduate Economic Review, Vol. 7: Iss. 1, Article 2.

Firmansyah, I. dan Rusydiana, A. (2013). Pengaruh Profitabilitas Terhadap
Pengeluaran Zakat pada Bank Umum Syariah di Indonesia dengan Ukuran Perusahaan sebagai Variabel Moderasi. Jurnal Liquidity, Vol. 2, No. 2, hlm. 110116

Harahap, S. S. (2008). Analisis Kritis atas Laporan Keuangan. Jakarta: PT Raja Grafindo Persada.

Ikhwan, K. A. (2000). Analisis Pengaruh Kinerja Keuangan terhadap Kemampuan Zakat pada Lembaga Keuangan Syari'ah (Studi pada Baitul Mal wat Tamwil (BMT) Binaan PINBUK Jawa Tengah). (Tesis). Program Pascasarjana Universitas Diponegoro

Jayanti, W. T. et al. (2015). Pengaruh Kinerja Keuangan Terhadap Zakat Bank Umum Syariah Yang Terdaftar Di Bank Indonesia Periode 2010-2014. Artikel

Maybank Syariah. (2016). Laporan Keuangan dan Tahunan. [Online]. Diakses dari www.maybanksyariah.co.id

Mega Syariah. (2016). Laporan Keuangan dan Tahunan. [Online]. Diakses dari www.megasyariah.co.id

Nurhayati, S. dan Wasilah. (2013). Akuntansi Syariah di Indonesia. Jakarta: Salemba Empat.

Panin Bank Syariah. (2016). Laporan Keuangan dan Tahunan. [Online]. Diakses dari www.paninbanksyariah.co.id

Rokhmana, S. N. (2015). Analisis Pengaruh Kinerja Keuangan terhadap Kenerja Sosial Bank Umum Syariah Di Indonesia Tahun 2010-2014. (Tesis). Program Pascasarjana UIN Sunan Kalijaga

Sari, R. A. (2012). Pengaruh Karakteristik Perusahaan terhadap Corporate Social Responsibility Disclosure pada Perusahaan Manufaktur yang Terdaftar di Bursa Efek Indonesia. Jurnal Nominal, Volume 1 Nomor 1, hlm. 124-140

Stiawan, A. (2009). Analisis Pengaruh Faktor Makroekonomi, Pangsa Pasar dan Karakteristik Bank terhadap Profitabilitas Bank Syariah (Studi pada Bank Syariah Periode 2005-2008). (Tesis). Program Pascasarjana Universitas Diponegoro 
Syaifudin, M. (2016). Pengaruh Kinerja

Keuangan terhadap Zakat Perbankan

Syariah di Indonesia dengan Size Bank

sebagai Variabel Moderasi. (Tesis).

Program Pascasarjana UIN Sunan

Kalijaga

Syariah Bukopin. (2016). Laporan Keuangan dan Tahunan. [Online]. Diakses dari www.syariahbukopin.co.id

Syariah Mandiri. (2016). Laporan Keuangan dan Tahunan. [Online].

Triyuwono, I. (2012). Akuntansi Syariah: Perspektif, Metodologi, dan Teori Edisi Kedua. Jakarta: Rajawali Pers.

Undang-Undang No. 21 tahun 2008 tentang Perbankan Syariah

Undang-Undang No. 38 tahun 1999 diperbarui menjadi Undang-Undang No. 23 tahun 2011 tentang Pengelolaan Zakat

Zaitun, S. (2000). Analisis Pengaruh Rasio Profitabilitas terhadap Zakat pada PT. Bank Muamalat Indoensia. (Tesis). Program Pascasarjana Universitas Diponegoro 